\title{
Estado laico, ensino religioso e intolerância: os desafios da educação pública
}

\author{
Emerson Sena da Silveira ${ }^{1}$
}

\begin{abstract}
Resumo: A reemergência de intolerâncias e configurações político-religiosas de extrema-direita ou direita nacional-populista, colocou grandes desafios ao ensino público entendido como espaço de construção de convivência com a alteridade. A deterioração político-social acentuou-se durante a sindemia de COVID-19 e lança uma interrogação: dentro da educação público-estatal, o ensino religioso pode cultivar espaços de produção de intersubjetividades livres, autônomas e cidadãs? Para responder ao questionamento, proponho uma reflexão filosófico-sociológica, alicerçada metodologicamente em literatura acadêmica corrente, documentos primários e secundários online e físicos. A laicidade estatal permitiu o ensino público laico, democrático, republicano. Inicialmente constituído como reação religiosa católica às perdas dos laços oficiais com o Estado, o Ensino Religioso só começou recentemente, uma nova página de sua história, mais próxima da laicidade plural. Porém, embates religiosos reacionários atrasam a implantação do padrão curricular comum, a Base Nacional Curricular Comum (BNCC). Para superar os desafios, será necessário ver a educação pública e o ensino religioso como bens comuns, plurais e laicos a que todos têm direito, constituindo-se em espaços de contraposição à intolerância religiosa.
\end{abstract}

Palavras-chave: Ensino Religioso. Laicidade e Educação Pública. Bens comuns.

\section{Secular state, religious education, and intolerance: the challenges of public education}

\begin{abstract}
The re-emergence of intolerances and political-religious configurations of the far-right or the national-populist right, posed great challenges to public education understood as a space for building coexistence with otherness. The political-social deterioration was accentuated during the COVID-19 syndrome and raises a question: within public-state education, can religious education cultivate spaces of production of free intersubjectivities, autonomous and citizens? To answer the question, I propose a philosophical-sociological reflection, based methodologically on consecrated academic literature, online and physical primary and secondary documents. State secularism allowed secular, democratic, republican public education. Initially constituted as a Catholic religious reaction to the loss of official ties with the State, Religious Studies only began recently, a new page of its history, closer to plural secularism. However, reactionary religious clashes delay the implementation of the common curricular standard, the Common National Curricular Base (BNCC). To overcome the challenges, it will be necessary to see public education and religious education as common, plural, and secular goods to which everyone is entitled, constituting spaces of opposition to religious intolerance.
\end{abstract}

\footnotetext{
${ }^{1}$ Doutor em Ciência da Religião. Professor do Programa de Pós-Graduação em Ciência da Religião da Universidade Federal de Juiz de Fora (UFJF). Minas Gerais, Brasil. E-mail: emerson.pesquisa@gmail.com Orcid: https://orcid.org/0000-0002-5407-596X
} 
Keywords: Religious Teaching. Secularism and Public Education. Commons.

\section{Estado laico, enseñanza religiosa e intolerancia: los desafíos de la educación pública}

Resumen: La reaparición de intolerancias y configuraciones político-religiosas de extrema derecha o de derecha nacional-populista, planteó grandes desafíos a la educación pública entendida como un espacio para construir convivencia con la alteridad. El deterioro político-social se acentuó durante el síndrome COVID-19 y plantea una pregunta: dentro de la educación público-estatal, ¿puede la educación religiosa cultivar espacios de producción de intersubjetividades libres, autónomas y ciudadanas? Para responder a la pregunta, propongo una reflexión filosóficosociológica, basada metodológicamente en literatura académica consagrada, documentos primarios y secundarios físicos y en línea. El laicismo estatal permitía la educación pública laica, democrática y republicana. Inicialmente constituida como una reacción religiosa católica a la pérdida de los lazos oficiales con el Estado, la Enseñanza Religiosa sólo comenzó recientemente, una nueva página de su historia, más cercana al laicismo plural. Sin embargo, los enfrentamientos religiosos reaccionarios retrasan la aplicación de la norma curricular común, la Base Curricular Nacional Común (BNCC). Sin embargo, los enfrentamientos religiosos reaccionarios retrasan la implantación del estándar curricular común, la Base Nacional Curricular Común (BNCC). Para superar los desafíos, será necesario ver la educación pública y la enseñanza religiosa como bienes comunes, plurales y laicos a los que todos tienen derecho, constituyéndose en espacios de contraposición a la intolerancia religiosa.

Palabras-clave: Enseñanza Religiosa. Laicidad y Educación Pública. Bienes comunes.

\section{Introdução}

A relação entre laicidade, escola pública, intolerância religiosa e ensino religioso é longa e complexa, flutua ao sabor das investidas e contra-investidas de correntes políticas e religiosas. Requer uma entrada específica. No presente texto, pontuarei a trama entre ensino religioso, intolerância religiosa e laicidade. Farei distinção entre o laico e o secular, refletirei sobre a intolerância religiosa e os problemas de constituição do Ensino Religioso (ER).

Para fechar o circuito, trarei percursos históricos do ER, abordarei o enquadramento contemporâneo religioso e os movimentos de submissão do laico e do público aos ditames do religioso reacionário. Para contrapontuar, ressaltarei as ameaças ao princípio da laicidade no campo da escola pública em tempos de grave crise de saúde pública, econômica, social e política.

Embasado em literatura consagrada de pesquisadores da educação, da laicidade e da política, puxarei para o texto fontes primárias e secundárias físicas e online, além de documentos essenciais para a discussão dos desafios contemporâneos ao Estado laico, a 
educação pública e ao Ensino Religioso.

\section{Laicidade, secularização e regime de crenças na contemporaneidade}

Ranquetat Jr. (2008) distingue laicização e secularização como fenômenos específicos e contextuais, embora possuam similaridade. Ambos os processos se avultaram com a modernidade, entre os séculos XVI e XX e exprimiram um projeto civilizacional-cultural que sucedeu a civilização cristã ou cristandade após um longo período de vigência, ao menos entre os séculos VI ao XVII. Laicidade e secularização estão conectadas aos processos de transformação vividos entre religião, sociedade, igreja e aparato estatal em países católicos e protestantes, europeus, norte-americanos e latino-americanos. O processo de secularização, com antigas raízes sociais, simbólicas, jurídicas e religiosas no próprio contexto do pensamento judaico-cristão, erodiu o monopólio da religião institucionalizada (igrejas) sobre a cultura, a sexualidade, a sociedade e as consciências individuais. Aconteceu uma profunda transformação social: a institucionalização do pluralismo cultural-religioso e a perda do monopólio das justificativas metafísico-religiosas (PIERUCCI, 1998; BERGER, 1989).

No curso da longa história, após as Guerras de Religião (1618-1648), a Revolução Americana (1776), a Revolução Francesa (1789) e a Expansão Napoleônica (1800-20), houve, pelo Mundo Ocidental, fortes movimentos de separação jurídica entre a estrutura estatal e as poderosas igrejas hegemônicas, católica e protestante. Esses processos amplos, históricos e tortuosos, se mesclaram e/ou inspiraram processos de luta por liberdade e justiça social nas antigas colônias europeias nas Américas e África ao largo de longo tempo (revoltas, revoluções, descolonizações, insurreições). (OLIVEIRA, 2015, FANON, 1961). Nas compridas, dolorosas e seculares lutas dos povos originários e das sociedades colonizadas, a laicidade foi um dado importante, construído a duras penas, em especial a recusa do religioso institucional - católico ou protestante - como elemento mais forte do aparato estatal. (CAMURÇA, SILVEIRA, ANDRADE, 2020). Ao observar esses grandes processos, notam-se detalhes dentro das periferias coloniais, num primeiro momento, capitalistas, num segundo momento e, agora, no terceiro momento, capitalistas extrativistas-globalizadas-financeiras (DOWBOR, 2020).

Na história colonial brasileira, um vasto sistema escolar foi criado pelas mãos dos Jesuítas, apesar das exclusões dos negros escravizados e das mulheres. As mutações 
civilizacionais e a violência da dominação colonial portuguesa abateram-se sobre a Ordem Jesuíta, expulsa do Brasil por um ato do Marquês de Pombal. Desagregou-se todo um sistema de ensino e substituiu-se por outro, às pressas (OLIVEIRA, 1973; PAIVA, 1982). As proibições de Portugal retardavam e prejudicavam o desenvolvimento educacional brasileiro. No reinado da Rainha Dona Maria I (a louca para os brasileiros; a piedosa, para os portugueses), o Iluminismo se espalhou pela Europa, mas repressão colonial aumentou e com ela, a censura contra ideias novas e grupos rebeldes, em especial, no campo educacional (SAVIANI, 2007). Em termos históricos, o Brasil sofreu exclusão educacional a partir de processos coloniais violentos: índia(o)s, negra(o)s e mulheres brancas estavam desde logo excluída(o)s, assim como os homens brancos pobres (GHIRALDELLI, 2006, SAVIANI, 2007). Os filhos dos senhores de engenho com acesso a alguma educação, estavam submetidos a um regime antipedagógico, autoritário, violento, que marcou muito negativamente o desenvolvimento social e educacional brasileiro. Durante séculos, recorreu-se à violência física para educar: palmatória, xingamento, humilhações (FREYRE, 1984; VIANNA, 1945).

Os detalhes históricos que complexificam os amplos processos de laicidade e libertação social, estão relacionados às trajetórias específicas das minorias, negra e indígenas, e os processos de invisibilização de seus direitos, religião e cultura, o que ampliou a intolerância religiosa, entendida aqui como perseguição e cerceamento de práticas, crenças e ideias religiosas (SILVA, 2007). A intolerância religiosa nasce da tentativa de grupos que anseiam o retorno de uma hierarquia oficial. Diante do Estado laico, nenhuma crença pode ser oficial, prevalente sobre outra. O processo do secular e do laico, em suas idas e vindas, atingiu a educação formal pública e a moldou, a partir do momento em que crenças religiosas oficiais deixaram de valer como parâmetro cultural e regra legal a que todos devem obedecer, sob pena de sanções e criminalização.

A tarefa educacional pública passou às mãos do Estado e não mais das instituições religiosas. Estas, por sua vez, depois de tentarem reaver o poder perdido, aquietaram-se, mas, quando movidas por reacionarismo moral-social e quando acopladas a correntes políticas de direita ou extrema-direita (fascista, nacionalpopulista, anarcocapitalista), oferecem, na contemporaneidade, em maior ou menor grau, resistência ao processo laico-estatal, tentam readquirir a hegemonia da educação 
pública e, quando não conseguem, negociam exceções ou enclaves (ROCHA, SOLANO, 2019). Numa breve conceituação, assumirei que o reacionarismo religioso, em especial o cristão, é subjetivamente fascista, está em guerra contra o mundo moderno e seu quadro pluralista e diversificado: múltiplos arranjos familiares, sexualgêneros, minorias, políticos e ideológicos (SILVA, SILVEIRA, 2020).

O nacional-populismo de direita, e suas variações, por outro lado, reemergem a partir da crise mais profunda do capitalismo, em especial após 2008. Todo pensamento social aponta os problemas inerentes à dinâmica de produção capitalista que procura sua própria autorrealização no lucro e na mais-valia. Esses grupamentos não se dão conta desses crises e suas consequências, e, para enfrentá-las, mobilizam a ideia de nação, contra os fluxos e estruturas transnacionais; a ideia/prática de democracia direta e reativa-ressentida, contra a democracia liberal-representativa e contra as regras impessoais e gerais da república; a ideia de valor moral absoluto contra a pluralidade valorativa do mundo globalizado; a ideia/prática de liberdade absoluta, acima de tudo/todos, contra a suposta tirania do "sistema" e das normas civilizatórias; a ideia/prática de guerra contra práticas, pessoas e ideias diversas e diferentes, agrupados sob rótulos como "comunismo", "ideologia de gênero", "cristofobia".

Em geral, os rótulos são sinalizadores negativos, acusatórios e servem para assinalar os que são considerados "inimigos". Assim, esses movimentos julgam que os "inimigos" devem ser eliminados ou, caso não se consiga, submetidos, não importa se está em jogo um papa católico que defende o meio-ambiente, os migrantes e pobres e a justiça social, um youtuber negro ou LGBTQIA+ que critica o racismo e a homofobia, um político que propõe igualdade social, um livro didático que fale sobre as torturas do Regime Militar, sexo do corpo humano ou religiões de matriz-africana e sua simbologia (os orixás, Exu, Oxum, Xangô, Oxalá, Iansã, Iemanjá, Nanã, Oxóssi, Ogum), dentre uma enorme população de coisas ideias, práticas pessoas e grupos.

Não à toa, essas correntes mobilizam massas de frustrados, pessoas em situação de penúria, trabalhadores precarizados, setores das elites e classes médias (insatisfeitos e incultos) que se conectam aos movimentos religiosos reacionários. Ambas as movimentações se encontram entrelaçadas por uma afinidade romântica-conservadora forte e emergem com a crise econômica do capital financeiro (DOWBOR, 2020; GHIRALDELLI, 2021). A junção dos movimentos oferece obstáculos aos processos e estruturas laicizadas, inclusive as educacionais. É um terreno pantanoso de teorias 
conspiratórias que grassam e afetam negativamente as políticas estatais de saúde pública e de educação formal. Se ao quadro reacionário-religioso somam-se governantes que, ao emergir com esses movimentos, os promovem e com eles se identificam, como Donald Trump (EUA) e Jair Bolsonaro (Brasil), o risco de anomia na sociedade e o de dissolução do aparato republicano e seus atributos de impessoalidade, igualdade, universalidade. é imensurável, pois aumenta com o tempo de permanência desses governos/governantes no poder estatal.

Por isso, os processos de laicidade estatal efetivaram-se na jovem República Brasileira (CARVALHO, 1987). O movimento construído por setores do exército, intelectuais positivistas, políticos republicanos, setores da Igreja Católica, das oligarquias rurais insatisfeitas com o fim da escravatura negra e os incipientes segmentos urbanos, destruiu o Regime do Padroado que desde o século XVI governava a vida brasileira e sua educação. Esse regime designava um conjunto de privilégios oficiais concedidos pela Santa Sé aos reis de Portugal e de Espanha por meio de bulas pontifícias (CARVALHO, 1987). O Padroado, que abrangeu o período colonial e republicano brasileiro, era um instrumento jurídico medieval que dava autoridade ao monarca para gerir aspectos administrativos, jurídicos e financeiros do catolicismo, inclusive aspectos educacionais. A religião católica, representada pela Igreja, era a religião oficial, e seus dogmas eram ensinados como dever e herança a ser imposta a todos.

Durante os processos de laicização, os discursos religiosos institucionalizados foram forçados a renunciar ao uso da coerção, violência simbólica, censura e imposição violenta das verdades de uma expressão de fé sobre as estruturas sociais, dentre elas, as educacionais. No contexto da formação do espaço e da esfera pública a partir da Proclamação da República, o poder moderador religioso recuou, mas ainda procurou manter suas influências sobre o aparato estatal. Assim, na primeira Constituição republicana (1892), a administração de cemitérios, o registro civil, o casamento e a educação pública passaram para registros não-clericais. Houve reações católicas. Um dos principais personagens do avanço católico sobre os organismos políticos e educacionais da República, foi Dom Sebastião Leme, arcebispo do Rio de Janeiro. (CALDEIRA, 2011). No movimento de rearranjo do poder político, as cisões nas oligarquias e no exército, as movimentações sociais de camadas urbanas, o operariado, a indústria e mais agente, levaram Getúlio Vargas ao poder e este governante empreendeu 
mudanças na área educacional, mas, ao mesmo tempo, aproximou-se da Igreja Católica.

Em 1931, junto com Getúlio Vargas, Dom Sebastião Leme inaugura a estátua do Cristo Redentor, no Morro do Pão de Açúcar, na então Capital Federal. Em uma carta pastoral, escrita em 1916, quando ainda era bispo de Olinda e Recife, trazia críticas à indiferença religiosa, ao agnosticismo secular e positivista da maioria dos intelectuais brasileiros e a falta de "doutrina" dos leigos e pensadores católicos. Era necessário cristianizar (catolicizar) a sociedade e seus setores importantes, como a educação. Sob o comando de eclesiásticos e leigos, a Igreja Católica reorganizou-se internamente e pressionou o governo federal e os estaduais, mobilizando a ideia de nação católica (CALDEIRA, 2011). Àquela época, mais de $90 \%$ dos brasileiros professavam o catolicismo como identidade religiosa. Em 1932, Amoroso Lima é eleito secretáriogeral da Liga Eleitoral Católica (LEC), criada por Dom Sebastião para efetivar as pressões sobre o Estado. A ideia era que a República incorporasse em seus quadros governamentais, a intelligentsia católica. A LEC seria uma espécie de grupo de pressão para assegurar a aceitação dos princípios católicos (negação do divórcio, ensino religioso nas escolas públicas, não ao aborto) pelos candidatos de todos os partidos nas eleições de 1933. Mas, a liga naufragou e, desde então, os candidatos católicos se articularam de modos variados, muitos deles ligados a movimentos de cunho igualitário-social, como as Comunidades Eclesiais de Base (CEBs) e a movimentos de cunho conservador-intimista, como a Renovação Carismática Católica (RCC) até chegarem, na contemporaneidade, à Frente Parlamentar Católica (CÂMARA DOS DEPUTADOS, 2015).

Em 1932, Getúlio Vargas enfrentou a Revolução Constitucionalista, movimento armado paulista que reivindicava o retorno das eleições e da Constituição. Vargas venceu o conflito, e convocou uma assembleia constituinte com a finalidade de elaborar uma nova carta constitucional. Em torno da nova Constituição de 1934 é que os embates sobre "Ensino Religioso" e "Ensino Laico" se acirraram. De um lado um pensamento católico conservador, enaltecendo as virtudes da autoridade, da moralidade, do catolicismo e do nacionalismo, vistos como se fossem uma unidade (ser católico é ser brasileiro, moralmente correto e temente às autoridades segundo se dizia). De outro lado, um grupo composto de intelectuais (Anísio Teixeira, Fernando de Azevedo, Lourenço Filho), criadores do movimento da Escola Nova, e que estiveram em contato com novas realidades sociais, como a da sociedade estadunidense. Influenciados pela 
filosofia norte-americana do pragmatismo, tinham princípios opostos aos defendidos pelos intelectuais católicos e liberais vetero-republicanos.

O Manifesto dos Pioneiros da Educação Nova (1932) foi uma força fundamental da laicidade, pois defendia uma escola pública de acesso universal, laica e gratuita (TEIXEIRA, 1954; 1963; 1968). É em torno da escola desvinculada da religião que as duas correntes empreenderão a batalha pelo poder de influenciar a elaboração da Constituição de 1934. Nesse contexto, um grupo de leigos católicos criou o Centro Dom Vital, dirigido por nomes como Alceu Amoroso Lima, representante leigo autorizado pela Igreja junto ao governo Vargas, defendeu com vigor, o Ensino Religioso nas escolas públicas, mas com viés não-laico. Durante 1934, a elaboração da Constituição trouxe um acalorado debate entre esses dois grupos. O grupo da Escola Nova conseguiu vencer em algumas proposições, mas perdeu a maioria dos argumentos, entre eles o fato de o Estado endossar a oferta de Ensino Religioso e a participação facultativa dos alunos nas aulas. A articulação do grupo católico venceu com a permissão da religião (a católica) nas escolas públicas, a proibição do divórcio e o reconhecimento do casamento religioso pela lei civil.

O ER foi mantido como monopólio nas mãos de padres e leigos. Um dos mais poderosos mecanismos de controle para garantir a hegemonia católica era a autorização do bispo diocesano para lecionar a disciplina. Em tempos mais recentes, anos 19802000, o lobby evangélico-religioso, somado ao católico, sobre o Estado, garantiu a confessionalização, repartindo influências, católicos, evangélicos e outras fés, como a afro-brasileira. Em algumas cidades e estados brasileiros, a adotaram e passaram a exigir que os professores e professoras tivessem autorização de suas respectivas instituições, o que, na prática, destrói o princípio da laicidade e submete a educação às influências religiosas institucionais.

A Constituição de 1937, feita depois do golpe de estado getulista corre paralela à opção política de Gustavo Capanema, ministro da educação do governo Getúlio Vargas em se aliar Igreja Católica, tentou-se imprimir à educação um caráter homogêneo e nacionalista. Convergem, a religião e a política. Em que sentido? Os rituais patrióticos (culto à bandeira, datas nacionais, heróis-mártires como Tiradentes) carregam uma sacralidade, uma imanentização de categorias religiosas. Essa convergência pode ser lida na chave da produção da disciplina, e consequentemente, na produção de regimes de verdade, historicamente construídos. Em 1945, com o fim da Segunda Guerra 
Mundial, o Estado Novo vai à ruína. A deposição de Getúlio Vargas por amplos setores sociais é precedida pela convocação de um novo processo constituinte. A Constituição de 1946 retomou, em linhas gerais, a pauta de educação da Carta Constitucional de 1934 e lançou os elementos antecedentes da primeira lei de Diretrizes e Bases da Educação.

Nas décadas de 1950 e 1960, apesar de movimentos reacionários como a TFP (Tradição, Família e Propriedade), a Igreja incorporou e desenvolveu práticas de cunho mais social-igualitário. Estão aí, as pastorais sociais, os conselhos de justiça e paz dentro da Conferência Nacional dos Bispos do Brasil (CNBB), criada em 1952. A proposta básica da escola pública era ampliar o saber oriundo de diversas heranças culturais ocidentais e consolidar a cidadania, a partir de um currículo enriquecido com línguas - latim, grego, francês, inglês, filosofia, história e uma sólida formação humanista (TEIXEIRA, 1968).

Por essa época, surgiram também grandes educadores como Darcy Ribeiro, e sua proposta de escola pública laica, incluindo a tentativa de produzir uma teologia desligada de elementos institucionais religiosos. A escola pública das décadas de 1950 e 1960 foi considerada uma das melhores, mas não era universal. Era escola na qual as minorias sociais, indígenas(o)s, negra(o)s, camponeses e outras minorias eram excluídas, impossibilitadas de acessar os conhecimentos e aprendizados clássicos e, simultaneamente, seus saberes e práticas, eram desvalorizados e censurados (SAVIANI, 2007). No campo educacional os paradigmas mudaram, surgindo o Movimento pela Educação de Base (MEB), cuja proposta se inspirava nas reflexões do pedagogo e educador Paulo Freire que, para vencer o abismo entre a cultura escolar clássica e as realidades vividas e sabedorias populares, propôs nova visão pedagógica, superando concepções elitistas e equivocadas (educação bancária).

De início eram poucos, mas os intelectuais católicos de esquerda atuavam fortemente por uma educação popular que estimulasse a autonomia e a capacidade de os sujeitos se apropriarem de suas histórias e raízes e, simultaneamente, estabelecessem pontes com o conteúdo clássico da educação, os conteúdos formais. Com o golpe cívico-militar de 1964, apoiado por setores das classes urbanas e empresariais, governadores, exército e intelectuais e religiosos de direita (católicos e evangélicos), e durante todo o Regime Militar, a situação do ER acentuou sua dependência religiosa, agravada pela ideia de moral e cívica, completamente desligada da ideia de direitos humanos, liberdade e igualdade social. 
A partir de 1964, a Ditadura Militar abortou uma série de projetos pedagógicos inovadores, como os de Paulo Freire no sertão nordestino; censurou, matou e torturou intelectuais, educadores, pedagogos, filósofos, sociólogos, professores, estudantes e militantes políticos (FREIRE, 1999; GADOTTI, 1980). As reformas autoritárias não melhoraram o sistema educacional, ao contrário, sucatearam o currículo e salário do magistério e introduziram ideias equivocadas: o persistente chamamento para uma educação profissional exclusivamente voltada para o mercado de trabalho, o pensamento técnico-conservador e o fatiamento do ensino em módulos, eixos, partes, erros que fustigaram a educação pública (TELLES, 1979; GHIRALDELLI, 2006). Essas ideias grassaram por essa época, mas permaneceram e foram abraçadas nos últimos trinta anos, por governos de direita e esquerda, sem exceção, e, a partir do governo de Michel Temer, com a reforma do Ensino Médio, atingiram o auge.

Por outro lado, a Igreja começou a desenvolver outra relação educacional: com a emergência da Teologia da Libertação e das CEBs, trazia críticas duras ao regime, por outro lado, outros setores católicos o apoiavam. O Exército, ao arrogar-se em poder moderador, assumiu a condução do processo educacional a partir de um projeto disciplinador, defendendo o enraizamento de um "espírito" calcado em bases nacionalistas, "enaltecendo" o progresso (tecnocrático, demolidor do meio-ambiente) baseado no predomínio de uma tecnocracia acrítica e desengajada da busca da justiça e igualdade sociais. Aumentaram os cursos de educação física, profissionalizantes e técnicos, o culto à bandeira e a educação moral e cívica (uma espécie de religião civil), a sociologia e da filosofia se tornaram disciplinas opcionais, tudo envolvido por uma pedagogia tecnicista, pouco reflexiva e humanizadora.

Mas a sociedade se movimentava e transformava-se. Ao final de 1979, o Brasil começava toda uma mobilização em torno da redemocratização, a partir da Lei da Anistia. Retornavam ao Brasil, políticos e pensadores, entre eles o antropólogo Darcy Ribeiro, um dos autores da atual LDB. Uma longa mobilização política e social marcou a história brasileira, cujo auge foi o Movimento Diretas Já (1984-1985). Apesar da derrota do movimento - pois o Congresso não aprovou o projeto para permitir a escolha eleitoral direta do presidente, eliminando o Colégio Eleitoral - a luta pelos direitos sociais, entre eles o direito à educação, continuou. A discussão sobre um ER laico também, mas não alcançou volume e voz. Havia desconfianças dos grupos religiosos hegemônicos católicos, que desejavam manter os espaços conquistados e dos grupos 
mais laicistas, que não conseguiam vislumbrar a eficaz implementação do respeito à pluralidade religiosa e a abordagem cultural-histórica no ER.

Em 1986, o presidente José Sarney, que herdou o poder após a morte de Tancredo Neves, escolhido como presidente pelo Colégio Eleitoral, convocou uma Assembleia Nacional Constituinte. Setores e movimentos sociais, como os sindicatos de metalúrgicos e partidos políticos de esquerda, lideram a luta pela garantia dos direitos sociais e humanos. Ao fim de 1988, a carta aprovada e promulgada, consagrava a liberdade de crença e culto religioso, numa tentativa de superar o preconceito e a perseguição às heranças culturais e religiosas dos africanos, expresso no patrimônio mitológico-ritual do Candomblé, por exemplo. Os direitos sociais e individuais foram equilibrados num enquadramento ao estilo do Bem-Estar Social: educação e saúde são direito de todos e dever do Estado, em sua responsabilidade tríplice, União, Estados e Municípios.

Mas somente em 1996 a LDB conseguiu um princípio de regulamentação em torno do Ensino Religioso. Este, a partir de então sofreu diversas variações, outros confrontos e convergências. Os capítulos dessa história não terminaram.

Por outro lado, a hipótese da laicidade estatal no Brasil possuir pouca força normativa e cultural é plausível. No ER da escola pública, a batalha para eliminar a influência religiosa institucional indevida é a mais acirrada e está longe do fim. O processo de laicidade não conseguiu promover "a secularização e assegurar sua própria reprodução", pelo contrário: esta tem "sido acuada pelo avanço de grupos católicos e evangélicos politicamente organizados e mobilizados para intervir na esfera pública" (MARIANO, 2011, p. 254). Esses grupos "gozam de situação legal privilegiada" e conseguem "volta e meia, através de seus lobbies e de sua representação parlamentar, forçar uma insuportável capitulação do poder público”. (MARIANO, 2011, p. 254).

A desvinculação entre Igreja e Estado, em termos de crenças e práticas oficiais, não resultou, portanto, na privatização do religioso, nem na exclusão mútua entre religião e política (MARIANO, 2011). Diferente dos casos francês, uruguaio e mexicano, não houve um grande e forte movimento anticlerical (MARIANO, 2011). Assim

laicidade não constitui propriamente um valor ou princípio nuclear da República brasileira, que deve ser defendido e preservado a todo custo, nem a sociedade brasileira é secularizada como a francesa e a 
inglesa $[\ldots]$ o que [...] constitui séria limitação às pretensões mais ambiciosas de laicistas". (MARIANO, 2011 p. 254).

Poucos se ativeram às implicações poderosas dessa reflexão, dentre elas, a dificuldade imensa de um Ensino Religioso laico e plural. Em 2009, o Congresso Nacional aprovou um acordo abrangente entre o Estado e a Santa Sé, em especial sobre o ER confessional e seu exercício em escolas públicas, o que motivou discussões e ações jurídicas de contestação. A concordata recebeu o nome de Acordo BrasilVaticano, editada pelo Decreto Federal no 7107/2010. O processo causou forte reação dos evangélicos, que propuseram um projeto de lei chamado Lei Geral das Religiões (PL 160/2009), arquivado em 2018 (SENADO FEDERAL, 2021).

Todavia, ao longo das duas últimas décadas, assistimos a reemergência da extrema-direita política aliada ao reacionarismo religioso cristão e ao neoliberalismo financeiro, que coloca enormes ameaças ao ensino público, incluindo à frágil laicidade do ensino religioso. Não obstante os vaivéns da laicidade à brasileira, as práticas de ER ocorrem desde seu retorno à escola pública, constituindo-se em um campo de uma disputa acirrada entre as religiões instituídas: o catolicismo, os evangélicos, pentecostais e neopentecostais, e os grupamentos com menor poder de influência, como os grupos afro-brasileiros e sua brava luta por reconhecimento e respeito às suas tradições religiosas. Nesse sentido, observam-se três vertentes de prática pedagógica na escola pública: a confessional ou catequética, que ensina dogmaticamente, a partir dos símbolos e valores dos agrupamentos religiosos [orientação católica para os católicos; afro-brasileira para os umbandistas e candomblecistas; evangélica para os evangélicos]; a cidadania sociocultural, baseada em valores e símbolos amplos, sem entrar propriamente na religião, e a fenomênica-histórica-cultural-religiosa, que apresenta a religião a partir de suas estruturas e fenômenos. Estados como o do Rio de Janeiro, enfatizam um ensino confessional, organizando as carreiras do magistério, currículos e materiais pedagógicos a partir de uma divisão entre católicos, evangélicos e afrofluminenses (umbanda e candomblé), principalmente. Em outros estados e municípios brasileiros, predomina uma forma mais próxima à da cidadania sociocultural. A última forma está em processo expansão, com iniciativas em diferentes lugares, tais como a proposta do Estado do Paraná (ESTADO DO PARANÁ, 2008). Todas essas vertentes pedagógicas baseiam-se em conjuntos de crenças, assim como os laicismos radicais e não-radicais. São as crenças que movem as ações práticas e estas conformam, informam, deformam e/ou confirmam as crenças. Mas, o que faz de uma crença, um ato 
de recusa ao convívio dialogal e à pluralidade, dois pilares das democracias sócioliberais-representativas e republicanas?

A resposta só pode ser investigada na conjunção de múltiplos planos e entrecruzamentos: a fragilização e atomização social produzida nos desdobramentos do neoliberalismo, a crise da democracia representativa-liberal e seus partidos (da esquerda à direita), o avanço dos grupos reacionários religiosos e civis sobre o aparato estatal, o imenso saldo de destruição social presente em nossa sociedade, acumulado ao longo de séculos e potencializado com a ascensão do anarcocapitalismo cristão-reacionário com as eleições presidenciais de 2018.

A história do ER no sistema escolar público é sinuosa, cheia de recuos e avanços devido às diferentes visões, pretensões e pressões de governos, grupos sociais, religiosos e acadêmicos. As escolas públicas brasileiras ora adotam um critério, ora outro; ora enfatizam uma formação específica (ciência ou ciências da religião ou teologia), ora uma formação básica em outra área complementada por um curso (livre, especialização lato sensu ou outro). Em relação ao professor e ao conteúdo curricular há múltiplas e conflitantes orientações. Não há uma posição oficial do Ministério da Educação e, com isso, materiais didáticos de baixa qualidade não são incomuns. Em alguns livros, registraram-se expressões discriminatórias em nome da fé, em geral cristã, contra a população formada por pessoas não heterossexuais, não-cristãs e/ou com algum tipo de deficiência (DINIZ, LIONÇO, CARRÃO, 2010).

No contexto da escola pública, tornou-se um território pouco normatizado, afeito a pressões religiosas católicas e evangélicas, com uma fragmentação regional e municipal enorme. Apenas recentemente os sinais de laicização e organização mais plural emergiram. Foram três versões e muitas discussões (BRASIL, 2015, 2016, 2017). A homologação da Base Nacional Curricular Comum (BNCC), em 2017, abriu os caminhos para que o conteúdo curricular seja, enfim, realmente laico e plural (LITTIG MILHOMEM FREITAS, 2021; SILVEIRA, JUNQUEIRA, 2020). A BNCC do Ensino Religioso estabelece ou tenta estabelecer, novos eixos, laicos e amplos, de abordagem do religioso e do não-religioso (ateísmo, agnosticismo, sem-religião) em sala de aula, trazendo competências e habilidades e temáticas que vão da identidade, ao mito, rito, organização, ideias, espaço das expressões religiosas monoteístas (judeus, cristãos, muçulmanos), orientais, indígenas, afro-brasileiras, pagãos e demais (SILVEIRA, JUNQUEIRA, 2020). Por isso, há, entre os estados brasileiros, uma grande variação na 
oferta, na organização pedagógica e na mão-de-obra. A nova Base Nacional Comum Curricular (BNCC) incluiu o Ensino Religioso como área de conhecimento do Ensino Fundamental. Foi a primeira vez que a União emitiu diretrizes curriculares, definiu unidades temáticas, objetos de conhecimento e habilidades relativas ao ER para serem, por fim, traduzidas sob a forma de disciplina escolar (LITTIG MILHOMEM FREITAS, 2021; SILVEIRA, JUNQUEIRA, 2020).

\section{Intolerância religiosa, escola pública e impasses concretos}

A partir da forte e crescente atuação de movimentos religiosos exclusivistas, em especial cristãos, que não são novas, perfazem ondas sucessivas de ataque à laicidade e a escola pública, ao menos de tomarmos a história brasileira após a Ditadura Militar (1964-1985), nascem iniciativas contra-laicas junto aos poderes republicanos: o movimento Escola sem Partido, o movimento Homeschooling e o movimento de militarização. Ambos estão sob o abrigo dos grupos religiosos cristãos reacionários, evangélicos principalmente, mas com forte apoio católico conservador e desfiguram a Lei de Diretrizes e Bases da Educação (BRASIL, 1996) e os princípios de escola justa e socialmente inclusiva (BRASIL, 1988).

O primeiro cresceu em meados dos anos 2000, fundado por um procurador estadual, Miguel Nagib, aos tempos de sindemia de Covid-19. O tema da crise sanitária social será de suma importância nos futuros desdobramentos da educação pública.

Assumirei, com base nas discussões mais contemporâneas, que a crise da Covid19 é longa, múltipla, se abate sobre a sociedade e a escola, impõe severas mudanças e perdas, mas pode ser mais bem pensada com o termo sindemia (SINGER, 2009; HORTON, 2020). A destruição acelerada do meio-ambiente sob o atual modo de organização social, econômico e espacial capitalista financeiro, acelerou a convivência entre vírus selvagens, animais domésticos e seres humanos e trouxe sucessivas correntes de enfermidades que se expandiram a um ponto global e severo. $\mathrm{O}$ conceito de sindemia possibilita entender como as enfermidades se prolongam no tempo-espaço, pois envolvem uma malha social densa, pesada e multiforme. Nessa malha, é impossível entender a doença, se a isolamos em fatores. A sindemia só pode ser entendida, e enfrentada com eficácia, se as doenças são vistas como uma malha em que entram em sinergia, desigualdade social/racial, organização espaço-urbana e econômica, vacinas, 
variações e mutações viróticas, educação e informação, gestão coordenada em rede, apoio social e econômico, ou sua ausência. A enfermidade do novo coronavírus, inclusive suas mutações e seu poder destrutivo, é biopolítica, pois é fruto do modo de organização político-social e econômico predominante (HORTON 2020). No Brasil o problema é agravado por causa da fusão entre o vírus e o governo reacionário religiosoanarco-capitalista (GHIRALDELLI, 2021).

Retornando ao movimento Escola sem Partido, sua tese é tecnicista, vê o professor como reprodutor e instrutor, sendo contrário a conteúdos que discutam gênero e política nas escolas públicas (a suposta "doutrinação política”). Houve um declínio, para alívio da laicidade, a partir do momento em que legislações inconstitucionais, aprovadas em diversos municípios e estados, foram barradas no Supremo Tribunal Federal (STF). Mas, infelizmente, os estragos deixados nas escolas públicas entre professores, alunos, pais e gestores pedagógicos foram amplos, em especial o medo da censura, da perseguição e da judicialização (PENNA, 2016; MOURA, 2020). O ER foi impactado por esse pânico moral e trouxe retrocessos em relação ao direito e ao dever de trazer para a sala de aula, por exemplo, os direitos humanos e as expressões culturalreligiosas das matrizes afro-brasileiras (DORNELES et al, 2018).

O segundo tomou impulso com a quarentena e presença de deputados de extrema-direita na presidência da mais importante comissão legislativa, a Comissão de Constituição e Justiça, da Câmara dos Deputados (CCJ) (BIMBATI, 2021). Os grupos reacionários desconfiam da educação pública por um sentimento de seita, identitárioexclusivista, que os faz sentirem-se superiores aos ditames constitucionais da República, e por um ressentimento atroz, nascido do fracasso social e pessoal, que os faz buscarem no fanatismo reacionário, uma solução, falsa em última instância, para as crises da sociedade e da educação: educar em casa.

Os projetos em andamento no Congresso Nacional podem intensificar ainda mais a evasão escolar e produzir uma geração inteira de crianças jovens com desprezo às ideias religiosas e culturais diferentes das professadas pela família, piorando o quadro crônico e grave de intolerância político-religiosa (BAMBATI, 2021). Em tese, a estrutura republicana, em especial o ensino público, propõe/dispõe/impõe a impessoalidade, a laicidade das leis e normas a todos os cidadãos, o que afronta esses grupos religiosos-políticos por conta desses sentimentos e sensibilidades subjetivamente fascistas, embora envolvidos em anarcocapitalismo. Entendo essa formação como a 
dominante do cenário socioeconômico, político e religioso contemporâneo: a defesa do capitalismo financeiro e dos seus mecanismos mais extrativistas e perversos e a promoção da suposta liberdade absoluta do indivíduo (indivíduo auto-empreendedor, narcisismo doentio), perante o mundo, as regras republicanas e a escola pública.

O terceiro, o mais recente deles, nasceu da ideia de que as corporações militares poderiam gerir com eficiência as escolas públicas, sanando problemas sociais (drogadições, violências) por conta de um atávico sentimento de disciplina e ordem (SANTOS, CARA, 2020). O pressuposto é falso e nasceu de um grave problema: por pressões militares, a LDB (1996) não rege obrigatoriamente as escolas militares, do ensino médio ao superior. Criaram-se sentimentos de superioridade, nutridos pela velha ideia de que as Forças Armadas são o poder moderador do País e do Estado. Com a assunção ao poder do anarcocapitalismo bolsonarista, o movimento ganhou força e foi adotado por governos estaduais bolsonaristas (Paraná), não-bolsonaristas (Rio Grande do Sul), mas também os ligados às esquerdas institucionais, Partido dos Trabalhadores (PT) (Bahia). A atuação desses movimentos corre paralela ao problema da intolerância religiosa. Estudos mostram que o problema tem se agravado ao longo dos últimos anos e está relacionado ao racismo religioso e a incapacidade da democracia e da república brasileiras de respeitar e garantir direitos às minorias por vias institucionais e programas e ações públicas (SILVA, 2007). O acoplamento desses três movimentos promove as mais fortes ameaças à escola pública de qualidade e ao ER laico e plural.

Para termos uma ideia da extensão e profundidade do problema, mais de 50\% das denúncias de violência e intolerância entre 2011 e 2016 coletadas oficialmente (ameaças verbais, destruição física, perseguição em ambiente escolar), referem-se às religiões de matriz afro-brasileiras (umbanda, candomblé, tambor-de-mina, batuque, jurema). O restante envolve ateus, muçulmanos, católicos, evangélicos, orientais e as outras. Não obstante serem minoria, que deveria ser protegida, as religiões afrobrasileiras lidam com a desproteção e pouca eficácia do aparato legal e constitucional.

A entrada de grupos religiosos cristãos nas estruturas republicanas, ocupando cargos a partir de alianças, o que ocorria antes, ainda que em governo de esquerda, mas com maior velocidade no governo Jair Bolsonaro, contribui para o desmonte de mecanismos e processos de combate que vinham crescendo desde a Constituição de 1988, da Fundação Palmares às políticas de ação afirmativas. Pode-se dizer que as militâncias religiosas reacionárias e fanáticas, irmanam-se no princípio da realidade 
insuficiente: o fundamento e a "verdadeira realidade" está em algum lugar além da República e da Carta Constitucional. O ER foi marcado por lutas pela hegemonia da religião dominante, no caso o catolicismo, batendo-se por uma identidade própria, um currículo específico e uma formação adequada de professores (RODRIGUES, 2013; 2015 a; 2015 b).

O ensino público é minado por muitos problemas:

A inexistência de um Sistema Nacional de Educação no Brasil pode
ser uma das razões pelas quais a profissão docente se apresenta hoje,
extremamente diferenciada e fragmentada. Estados e municípios,
considerados entes autônomos, conforme a Constituição Federal de
1988, correspondem cada um a um sistema de ensino. Há professores
federais, estaduais e municipais; professores concursados e não
concursados; professores urbanos e rurais; professores das redes
pública e particular e das redes patronais profissionais (Sistema S); e
professores titulados e sem titulação. Essa situação origina planos de
carreira distintos (ou ausência de planos), salários diferenciados e
duplicação de jornada em carreiras diferentes: estadual/municipal;
pública/privada; educação básica/educação superior (SCHEIBE, 2010,
p. 984).

As pesquisas sobre a profissão de professor revelam duros desafios, em especial no ensino fundamental: baixos salários, deterioração das condições de trabalho (ex.: violência, material pedagógico ruim), longas jornadas, salas superlotadas, dificuldade de atualização, cobranças por maior desempenho sem contrapartidas estatais, infraestrutura escolar ruim (bibliotecas, salas, móveis, internet, esporte, contato com a natureza, música, transporte e merenda escolar) (OLIVEIRA, FELDFEBER, 2006). E em tempos de Covid-19, esses antigos problemas se multiplicam: risco de vida e mortes por contaminação virótica, a piora do quadro salarial e da formação pedagógica, os problemas sociais dos alunos (fome, distâncias, pouco apoio para acesso a tecnologias e dispositivos).

Levantamento do Comitê Técnico da Educação do Instituto Rui Barbosa, entidade que congrega os Tribunais de Contas Brasileiros com base nos dados do último Censo Escolar, mostram que 6,1 milhões alunos (26,91\%) das redes municipais de ensino e 3,7 milhões $(24,73 \%)$ das redes estaduais estão matriculados em escolas que apresentam ao menos um problema de infraestrutura (falta de água potável, banheiro, rede de esgoto, energia elétrica, internet). (JORNAL HOJE, 2021) Inviabilizam-se, assim, os protocolos de segurança para o enfrentamento da sindemia do novo coronavírus. 
Por outro lado, o ritmo lento e tortuoso da vacinação nos estados e municípios, a falta de apoio social e econômico justo e suficiente a um amplo conjunto de pessoas, ambos causados em grande parte pelo governo federal, prolongam os conflitos entre pais, professores, alunos, comunidades e prefeituras/governos. Por isso, falar de um ER com qualidade e sua contribuição contra os avanços da intolerância religiosa sem tocar em questões estruturais da educação e da sociedade brasileiras é um erro crasso. É preciso pensar, simultaneamente, a valorização salarial do professor, a infraestrutura escolar, as questões de currículo, plano pedagógico e linhas de orientação, apoio social aos alunos, reforço pedagógico (JUNQUEIRA, CORRÊA, HOLANDA, 2009; PASSOS, 2007; SOARES, 2007).

Há fortes movimentos na sociedade para que o ER adquira, de uma vez, a laicidade em plenitude. A BNCC é um primeiro passo (SILVEIRA, JUNQUEIRA, 2021). Na "Ação Direta de Inconstitucionalidade ao Acordo Brasil-Vaticano no que se refere ao Ensino Religioso Nas Escolas Públicas", a ADI 4.439, documento proposto pela Procuradoria Geral da República (2010, p. 4), lê-se:

De modo que, em face do princípio da unidade da Constituição, não é viável a adoção de uma perspectiva que, em nome da laicidade do Estado, negue qualquer possibilidade de ensino de religião nas escolas públicas. Mas tampouco se admite que, a partir de uma leitura unilateral do art. $210, \S 1^{\circ}$, da Carta, se transforme a escola pública em espaço de catequese e proselitismo religioso, católico ou de qualquer outra confissão.

A escola pública não é lugar para o ensino confessional e para o interconfessional ou ecumênico, pois este, ainda que não voltado à promoção de uma confissão específica, tem por propósito inculcar princípios e valores religiosos partilhados pela maioria, com prejuízo das visões ateístas, agnósticas, ou de religiões com menor poder na esfera sociopolítica. Com isso, a Procuradoria Geral da República (2010, p. 5) afirma:

[...] a única forma de compatibilizar o caráter laico do Estado brasileiro com o ensino religioso nas escolas públicas é através da adoção do modelo não-confessional, em que o conteúdo programático da disciplina consiste na exposição das doutrinas, das práticas, da história e de dimensões sociais das diferentes religiões - bem como de posições não-religiosas, como o ateísmo e o agnosticismo - sem qualquer tomada de partido por parte dos educadores. Estes, por outro lado, devem ser professores regulares da rede pública de ensino, e não pessoas vinculadas às igrejas ou confissões religiosas.

A compatibilidade entre a laicidade estatal e o ER só é possível quando este 
desenvolve conteúdos pedagógicos não-confessionais, não-apologéticos e traz em planos horizontais de abordagem, as tradições religiosas, incluindo a cristã, e nãoreligiosas (agnosticismo, ateísmo, sem-religião). Assim, diz a Procuradoria Geral da República (2010, p. 5):

Tal modelo, por não implicar endosso ou subvenção estatal a qualquer crença ou posição religiosa, é, como dito, o único compatível com o princípio da laicidade estatal. Apenas ele promove, em matéria de ensino religioso, um dos mais nobres objetivos constitucionais subjacentes ao direito à educação: formar cidadãos e pessoas autônomas, capazes de fazerem escolhas e tomarem decisões por si próprias em todos os campos da vida, inclusive no da religiosidade

O acirramento dos conflitos ficou claro na audiência pública convocada pelo STF (Supremo Tribunal Federal) para discutir a ação da Procuradoria Geral da República [ADI 4.439] contra o modelo confessional praticado em escolas públicas, expresso, de forma sutil no "Acordo entre a República Federativa Do Brasil e a Santa Sé Relativo ao Estatuto Jurídico da Igreja Católica no Brasil”. Podem-se citar, como exemplos de ingerência indevida, as legislações regulatórias que ferem a laicidade segundo a ótica do Conselho Nacional do Ministério Público (JANOT, 2016, p. 20):

As leis Estaduais $n^{\circ} 3.459 / 2000$ e $n^{\circ} 5.998 / 11$, que, respectivamente, instituiu o ensino confessional na rede pública de ensino básico no Estado do Rio de Janeiro e criou a obrigatoriedade da Bíblia Sagrada nas bibliotecas escolares [...] a Lei $\mathrm{n}^{\circ}$ 74, do Estado do Amazonas, a Lei ${ }^{\circ}$ 2.902/2004, do Mato Grosso do Sul, e a Lei $n^{\circ}$ 8.415/2003, do Rio Grande do Norte, que também adotaram a obrigatoriedade da Bíblia Sagrada nas escolas. Por outro lado, a Lei $n^{\circ} 1.864 / 2008$, do Estado de Rondônia, violou de modo ainda mais ostensivo o Estado Laico, ao oficializar a Bíblia Sagrada como livro-base de fonte doutrinária para fundamentar princípios, usos e costumes de comunidades, igrejas e grupos, tendo ainda ressaltado que tudo é feito com o expresso reconhecimento do Estado de Rondônia.

A razão do ministério público federal acima é clara: um Estado laico não pode oficializar crenças, nem símbolos, nem práticas religiosas majoritárias, como no caso do cristianismo, ou minoritárias e ateístas. Na modernidade social, em especial a partir de meados do século XIX, a religião de igreja tornou-se apenas mais uma das dimensões sociais (ciência, sexo, arte, política, mercado), sem privilégios maiores e suas crenças deixaram de ser oficiais.

A laicidade não deve ser confundida com a secularização. Esta última pode ser vista como a perda das determinações do religioso ou do sagrado [dessacralização] sobre o conjunto da vida social e cultural e suas esferas de valor (sentido weberiano): política, estética, jurídica, cultural, cognitiva-intelectiva-científica, sexual, educacional e 
econômica (WEBER, 1963). A laicização, por outro lado, está relacionada ao processo de destituição de crenças religiosas oficiais incrustadas no Estado e em suas legislações e estruturas, e por extensão, da educação pública. Se não há nenhum dogma religioso oficial, nem na cultura, nem no aparato estatal, as múltiplas expressões religiosas podem ser manifestar publicamente de maneira igual e justa. Sem possuir laço oficial com o Estado, nenhuma das expressões religiosas ou religiões, tem mais vantagem que outras. $\mathrm{Na}$ escola pública, em tese, a laicidade possibilita o respeito e o tratamento igualitário das expressões culturais-religiosas, partícipes dos processos históricos de constituição da sociedade brasileira.

A religião, personificada em uma instituição que se arroga o direito de moderadora da realidade, não tem o monopólio legal e legítimo para regrar, orientar e fundamentar as dimensões educacionais. Contudo, há dois problemas em andamento, derivados do avanço dos processos de secularização e laicização. Primeiro, se não é possível estabelecer laços oficiais gerais e uniformes, é possível aos governos privilegiarem igrejas e crenças dentro da estrutura estatal-republicana - como é possível notar com maior acuidade, no governo de direita populista extremada que dirige o país: o ministro da educação é pastor presbiteriano, muitos funcionários seus, ao menos os comissionados de livre-nomeação, são fiéis de igrejas evangélicas históricas, pentecostais e neopentecostais. Nos demais ministérios, como o de direitos humanos, a colonização religiosa do Estado se repete e produz um grave problema: uma tentativa de usar a estrutura para o serviço de duas ideias e a reprodução ideológica homogênea. Não há diversidade e diferenças substanciais em termos de prática e pensamento dentro dos segmentos religiosos que, por hora, ocupam postos de poder. Eles procuram dirigir as políticas públicas-estatais segundo uma visão reacionária, ou seja, segundo o desejo de recriar uma hierarquia de valores - os deles em primeiro - senão oficial, ao menos de fato, oficioso ou tácito, e segundo uma estratégia similar à que a Igreja Católica empreendeu ao ver que o Estado laico cortou os vínculos oficiais com a Proclamação da República. A constatação dessa severa colonização religiosa cristã, não exime os governos anteriores de problemas similares, desde a ascensão dos grupos evangélicos, com mais notoriedade em meados dos anos 1990, com poder de trazer votos e apoio político nas disputas eleitorais e durante as governanças.

É possível sair desses impasses, pois não é função do Estado criar legislações que oficializem determinadas posturas religiosas ou obriguem as escolas a adotar um 
procedimento pedagógico confessional, o que constitui uma postura contraproducente e pouco republicana. Um Estado laico, democrático e republicano permite a coexistência de uma pluralidade de vozes, entre as quais, as religiosas, e age com neutralidade em relação às confissões de fé, sem favorecimentos, mas, ao mesmo tempo, zela para que, no espaço e na esfera da educação pública, regras de convivência e diálogo sejam observadas por qualquer religião ou grupo não-religioso.

Os grupos religiosos cristãos reacionários e grupos políticos de extremadireita/nacional-populista (militarização das escolas, Escola sem Partido, Homeschooling), desejam se utilizar das estruturas republicanas - que garantem o bem comum, para cumprir não a função de origem, servir a população com políticas de igualdade, apoio, estímulo, mas a de servir-se para promover uma função religiosamoral particular. Desenha-se, portanto, uma nova luta para republicanizar o Estado, a educação pública e o Ensino Religioso, tornando-os um bem comum, a serviço de todos os cidadãos e por estes controlados e fiscalizados, o que não pode ser feito sem avançar a laicidade e o controle público organizado e sistemático das decisões, gestão e orçamentos.

\section{Referências}

BERGER, P. O dossel sagrado. Elementos para uma teoria sociológica da religião. São Paulo: Paulinas, 1989.

BIMBATI, A. P. Bia Kicis cria disputa para aprovar homeschooling e pode afetar 40 milhões. UOL NOTÍCIAS, São Paulo, 09/06/2021. Disponível em: https://educacao.uol.com.br/noticias/2021/06/09/bia-kicis-disputa-aprovar-educacaodomiciliar-afetar-40-milhoes-alunos.htm; acesso em: 14 jun. 2021 às 21:58.

BRASIL. Constituição. Constituição da República Federativa do Brasil. Brasília, DF: Senado Federal: Centro Gráfico, 1988.

BRASIL. Lei $n^{\circ}$. 9.394, de 20 de dezembro de 1996. Estabelece as diretrizes e bases da educação nacional. Diário Oficial da União, Brasília, 23 dez. 1996.

BRASIL. Base Nacional Comum Curricular. $1^{a}$ versão. Brasília: MEC, 2015.

BRASIL. Base Nacional Comum Curricular. $2^{a}$ versão. Brasília: MEC, 2016.

BRASIL. Base Nacional Comum Curricular. 3ªversão. Brasília: MEC, 2017.

CALDEIRA, R. C. Os baluartes da tradição: o conservadorismo católico brasileiro no Concílio Vaticano II. Curitiba: CRV, 2011.

CÂMARA DOS DEPUTADOS. Frente Parlamentar Mista Católica Apostólica 
Romana. Data de Publicação no DCD, 07/04/2015. Disponível em: https://www.camara.leg.br/Internet/deputado/frenteDetalhe.asp?id=53; acesso em 13 maio 2021 às 18:31.

CAMURÇA, M.; SILVEIRA, E. J. S.; ANDRADE JÚNIOR, P. M. DE. Estado laico e dinâmicas religiosas no Brasil: tensões e dissonâncias. HORIZONTE - Revista de Estudos de Teologia e Ciências da Religião, v. 18, n. 57, p. 975, 31 dez. 2020.

CARVALHO, J. M. de. Os bestializados: o Rio de Janeiro e a República que não foi. São Paulo: Companhia das Letras, 1987.

DINIZ, D., LIONÇO, T., CARRIÃO, V. Laicidade e ensino religioso no Brasil. Brasília: Unesco/ Letras Livres/Unb, 2010.

DORNELES, A. Et al (Orgs.). História, cultura e religiosidades afro-brasileiras Porto Alegre Editora Fi, 2018.

DOWBOR, L. O capitalismo se descola: novas arquiteturas sociais. São Paulo: Edições SESC, 2020.

ESTADO DO PARANÁ. Secretaria de Estado da Educação. Diretrizes Curriculares de Ensino Religioso. Curitiba: SEED, 2008.

FANON, F. Os condenados da terra. Lisboa: Editora ULISSEIA limitada, 1961.

FREIRE, P. Educação como prática da liberdade. 23. ed. Rio de Janeiro: Paz e Terra, 1999.

FREYRE, G. Casa Grande e Senzala: formação da família brasileira sob o regime da economia patriarcal. 23. ed. Rio de Janeiro: José Olympio Editora, 1984.

GADOTTI, M. Educação e poder: introdução à pedagogia do conflito. São Paulo, Cortez, 1980.

GHIRALDELli Jr., P. História da Educação Brasileira. São Paulo: Cortez Editora, 2006.

GHIRALDELLI Jr., P. A democracia de Bolsonaro. 2018-2020. São Paulo: CEFA Editorial, 2021.

HORTON, R. H. Offline: COVID-19 is not a pandemic. The Lancet, volume 396, issue 10255, p. 874, September 26, 2020.

JANOT, R. M. B. et al. Roteiro de atuação do Ministério Público. Estado Laico e ensino religioso nas escolas públicas. Brasília: Conselho Nacional do Ministério Público, 2016.

JORNAL HOJE. Portal G1 Notícias. Quase 10 milhões de estudantes estão em escolas públicas sem condições básicas de infraestrutura, aponta estudo. Disponível em: https://g1.globo.com/jornal-hoje/noticia/2021/06/15/quase-10-milhoes-de-estudantesestao-em-escolas-publicas-sem-condicoes-basicas-de-infraestrutura-apontaestudo.ghtml; acesso em: 15 jun. às 18:24. 
JUNQUEIRA, S., CORRÊA, R. L. T., HOLANDA, A. M. R. Ensino Religioso, aspecto legal e curricular. São Paulo: Paulinas, 2009.

LITTIG MILHOMEM FREITAS, E. M. Bem-me-quer, Malmequer: um estudo sobre a presença do ensino religioso na Base Nacional Comum Curricular. Revista Pistis Praxis, [S. 1.], v. 13, n. 1, jun. 2021.

MARIANO, R. Laicidade à brasileira Católicos, pentecostais e laicos em disputa na esfera pública. Civitas, Porto Alegre v. 11 n. 2 p. 238-258 maio-ago. 2011.

MIRANDA, S. R.; PEREIRA, J. S. Laicização e Intolerância Religiosa: desafios para a História ensinada. Revista Educação \& Realidade, Porto Alegre, v. 42, n. 1, p. 99-120. jan./mar. 2017.

MOURA, F. 5 teses corretas sobre o Escola Sem Partido. In: LIMA MENDONÇA, S. G. et al. (organizadores). (De)formação na escola: desvios e desafios. Marília: Oficina Universitária; São Paulo: Cultura Acadêmica, 2020, p. 149-168.

OLIVEIRA, B. A. de. As reformas pombalinas e a educação no Brasil. São Carlos, UFSCar, 1973.

OLIVEIRA, J. P. de. O nascimento do Brasil e outros ensaios: "pacificação”, regime tutelar e formação de alteridades. Rio de Janeiro: Contra-Capa, 2016.

OLIVEIRA, D. A., FELDFEBER, M. (orgs.). Políticas educativas y trabajo docente. ¿Nuevas regulaciones, nuevos sujetos? Buenos Aires: Centro de Publicaciones Educativas y Material Didáctico-Noveduc, 2006.

PAIVA, J. M. de. Colonização e catequese, 1549-1600. São Paulo, Cortez, Autores Associados, 1982.

PASSOS, J. D. Ensino Religioso, construção de uma proposta. São Paulo: Paulinas, 2007.

PENNA, F. O ódio aos professores. In: AÇÃO EDUCATIVA (org.). A ideologia do Movimento Escola Sem Partido - 20 autores desmontam o discurso. São Paulo: Ação Educativa, 2016. p. 93-100.

PIERUCCI, A. F. Secularização em Max Weber: da contemporânea serventia de voltarmos a acessar aquele velho sentido. Revista Brasileira de Ciências Sociais, São Paulo, v. 13, n. 37, p. 43-73, 1998.

PROCURADORIA GERAL DA REPÚBLICA, Ação Direta de Inconstitucionalidade ao Acordo Brasil-Vaticano no que se refere ao Ensino Religioso nas Escolas Públicas. Brasília: Procuradoria Geral da República, 2010. Disponível em: http://www.neppdh.ufrj.br/ole/textos/adi_stf.pdf; acesso em: 14 jun. às 23:45

RANQUETAT JR., C. A. Laicidade, laicismo e secularização: definindo e esclarecendo conceitos. Tempo da Ciência, v. 15, n. 30, p. 59-72, $2^{\circ}$ semestre 2008

ROCHA, C., SOLANO, E. (orgs.). As direitas nas redes e nas ruas. São Paulo: Expressão Popular, 2019. 
RODRIGUES, E. Questões Epistemológicas do Ensino Religioso: Uma proposta a partir da Ciência da Religião. Interações - Cultura e Comunidade, Belo Horizonte, Brasil, v.8 nº.14, p.230-241, jul./dez.2013.

RODRIGUES, E. Formação de professores para o ensino de religião nas escolas: dilemas e perspectivas. Ciências da Religião (Mackenzie. Online), v. 13, p. 19-46, 2015a.

RODRIGUES, E. Ciência da Religião e Ensino Religioso. Efeitos de definições e indefinições na construção dos campos. Revista de Estudos da Religião (REVER), São Paulo, v. 15, p. 55-66, 2015 b.

SANTOS, C. de A; CARA, D. T. Militarização das escolas públicas no Brasil e o financiamento: da educação como um direito à educação como privilégio. In: LIMA MENDONÇA, S. G. et al. (organizadores). (De)formação na escola: desvios e desafios. Marília: Oficina Universitária; São Paulo: Cultura Acadêmica, 2020, p. 167-190.

SAVIANI, D. História das ideias pedagógicas no Brasil. Campinas: Autores Associados, 2007.

SCHEIBE, L. Valorização e formação dos professores para a educação básica: questões desafiadoras para um novo Plano Nacional de Educação. Educação \& Sociedade, v. 31, n. 112, p. 981-1000, jul.-set. 2010.

SENADO FEDERAL. Projeto de Lei da Câmara n ${ }^{\circ}$ 160, de 2009. Situação: Arquivada ao Final da Legislatura Disponível em: 24 https://www25.senado.leg.br/web/atividade/materias/-/materia/92959; acesso em: 15 jun. 2021 às 17:00.

SINGER, M. Introduction to syndemics. A critical systems approach to Public and Community Health. San Francisco: Jossey-Bass, 2009

SILVA, V. G. da. (org.) Intolerância Religiosa: Impactos do Neopentecostalismo no Campo Religioso Afro-brasileiro. São Paulo: Editora da Universidade de São Paulo, 2007.

SILVEIRA, E. S. da, JUNQUEIRA, S. (orgs). O Ensino Religioso na BNCC. Teoria e prática para o ensino fundamental. Petrópolis: Vozes, 2020.

SILVA, E. F.; SILVEIRA, E. S. A pandemia de Covid-19 sob a benção de Bolsonaro e Evangélicos: mobilização política anti-ciência, saber mágico e pós-verdade. Inter-legere (UFRN), Natal, v. 3, p. 1-28, 2020.

SOARES, A. M. L. Religião e educação, da Ciência da Religião ao ensino religioso. São Paulo: Paulinas, 2007.

TELLES, S. S. Um projeto populista para o ensino: a universidade do trabalho. Educação \& Sociedade, São Paulo, v. 1, n. 3, p. 95-108, maio 1979.

TEIXEIRA, A. A crise educacional brasileira. Rio de Janeiro, MEC, Serviço de Documentação, 1954. (Os Cadernos de Cultura, 68). 


\section{Edurañâ,EscolarSociedade}

TEIXEIRA, A. Estado atual de educação. Revista Brasileira de Estudos Pedagógicos, Rio de Janeiro, 39(89):8-16, jan./mar. 1963.

TEIXEIRA, A. Educação e o mundo moderno. São Paulo: Cia Ed. Nacional, 1968.

VIANA, H. A educação no Brasil colonial. Revista Brasileira de Estudos Pedagógicos, Rio de Janeiro, v. 6, n. 18, p. 372-92, dez. 1945.

WEBER, M. Rejeições religiosas do mundo e suas direções". In: WEBER, M. Ensaios de Sociologia. Rio de Janeiro: Zahar Editora, 1963, p. 371-412. 